\title{
RECYCLING LOCAL INDUSTRIAL WASTES FOR PRODUCTION OF GREEN CONSTRUCTION MATERIALS
}

\author{
Alaa El-Din Sharkawi \\ Associate Professor, Structural Engineering Department, Faculty of Engineering, Tanta \\ University, Egypt. \\ E-mail: amsharka@ hotmail.com
}

\begin{abstract}
Industrial waste is one of the most important sources of environmental pollution in the world and Egypt. Providing economic opportunities for recycling these wastes represent an essential solution to this problem to encourage waste producers to dispose it safely and to provide an added value for these wastes. This research work will study the feasibility of recycling certain industrial wastes for production low-cost building materials and improving the soil compaction characteristics. In this research work, the efficiency of recycling some common local industrial wastes in production of construction materials was explored. The selected wastes include cement kiln dust (i.e. bypass) and ceramics powder. Previous researches and the chemical analysis showed that both wastes are promising as cement replacement materials. However, this exploratory phase is an initial investigation targeting the chemical properties of theses wastes for efficient use of both wastes to replace cement partially- in mortar and plain concrete elements as well as bricks. The advantage of replacing part of the cement content with waste materials has double environmental action, by which reducing cement use leading to less carbon dioxide emission in addition to the safe recycling of the industrial wastes. Based on the selected condition of the cement bypass and ceramic powder, no significant enhancement was recorded in the mortar and concrete mixes had various ratios of cement replacement. However, the main physical and mechanical properties of some of the tested mixes provided promising values for using these mixes for production of more green plain concrete, mortar and bricks. For the soil enhancement application, addition of cement bypass to soil -commonly found in delta region- increased the California Bearing Ratio (CBR) value of this soil by $300 \%$. Currently more comprehensive investigation is running to cover more than cement and ceramic factories in order to have a reliable data base of the properties of these types of industrial wastes and the efficient recycling of these wastes in construction materials and soil improvement applications.
\end{abstract}

Keywords: Industrial Wastes, Green construction materials, Cement Bypass, Soil improvement

\section{1- INTRODUCTION}

The potential benefits of using "green" raw materials to produce "green" construction materials are based mainly on the environmental impact while the potential barriers of such green applications are mainly due to the leak of knowledge and/or easy implementation. 
Aitcin (2008) estimated that 8.4 billion cubic yards of concrete were produced in 1997 worldwide, equivalent to 1.3 cubic yards per person per year. Concrete production (especially cement manufacturing) consumes a large amount of energy and also has negative environmental impact. As estimated by Aitcin (2008), the cement industry alone generates $7 \%$ of $\mathrm{CO} 2$ emissions worldwide. Also based on the current technologies, it is technically impossible to lower the energy consumption below the requirement of 3.79 Million Btu per ton (R. Collins 1993).

Robin L. Schroeder had summarized research work on those waste materials that had shown promise as a substitute for conventional materials focusing on new and innovative highway industry uses and he found that highway construction industry can effectively use large quantities of the following wastes materials:

- Blast furnace and steel slags.

- Carpet fibers.

- Coal ash byproducts, including fly ash, bottom ash, and FGD waste.

- Glass.

- Municipal solid waste combustion ash.

- Recycled plastic.

- Roofing shingle wastes.

- Rubber tires.

Cement kiln dust (CKD) is a significant by-product material of the cement manufacturing process. Over the past several years dramatic advances have been achieved, worldwide in the management and use of cement kiln dust, thus reducing it s dependency on landfill disposal. As with most large manufacturing of cement, by-product materials are generated. In many countries, the majority of CKD is recycled back into the cement kiln as raw feed. In addition, new technology has allowed the use of previously land filled CKD to be used as raw feed stock. Recycling this by-product back into the kiln not only reduces the amount of CKD to be managed outside the kiln, it also reduces the need for limestone and other raw materials, which saves natural resources and helps conserve energy(Wayne S. Adaska 2008).

Another principal use of CKD is for various types of commercial applications. These applications depend primarily on the chemical and physical characteristics of the CKD. The major parameters that determine CKD characteristics are the raw feed material, type of kiln operation, dust collection systems, and fuel type. Since the properties of CKD can be significantly affected by the design, operation and materials used in a cement kiln, the chemical and physical characteristics of CKD must be evaluated on an individual plant basis (Wayne S. Adaska 2008). Studies had shown that CKD can be used alone, but often is more effective when used in combination with other cementitious materials including portland cement, fly ash and slag. CKD containing high $\mathrm{CaO}$ content and low loss of ignition (LOI) performs best for most applications. High LOI dusts contain a higher percentage of bound water within its chemical structure and less $\mathrm{CaO}$ is available to react. The high LOI can also interfere with the hydration process. (Wayne S. Adaska 2008).

Cement kiln dust can be used to improve the properties of soil in situ, and as an activator in pozzolanic stabilized base mixtures. The adsorptive capacity and Cementitious properties of cement kiln dust allow it to reduce the moisture content and increase the bearing capacity of the soft soil and also to reduce construction time and costs. Cement kiln dust can be mixed with soil to modify plastic limits or moisture content to provide the desired stabilized properties. Ghorab (2007) t al, had proposed to use CKD for the chemical stabilization of different soil classifications along Egypt to produce building units such as bricks, tiles, 
paving roads and wall plaster. Ghorab (2007), had also tested the durability of the proposed stabilized soil units after exposure to various sever conditions (Ghorab 2007).

Cement kiln dust can be used as mineral filler in asphalt paving for applications in highway construction. Hot-mixed asphalt (HMA) is a common paving material as seen in figure (1) (Tara Sen 2010). Depending on their chemical composition, many researches had found that ceramic powder wastes were suitable to be used in the construction industry, and more significantly on the making of concrete. Ceramic powder wastes are found to be suitable for partial substitution of cement. Researchers were found that concrete having ceramic powder replacing cement was performing better than normal concrete specially durability performance. Thus to continue with further research in this area is necessary to have reliable information for using ceramic powder as stable binding material. (O. Zimbili 2014).

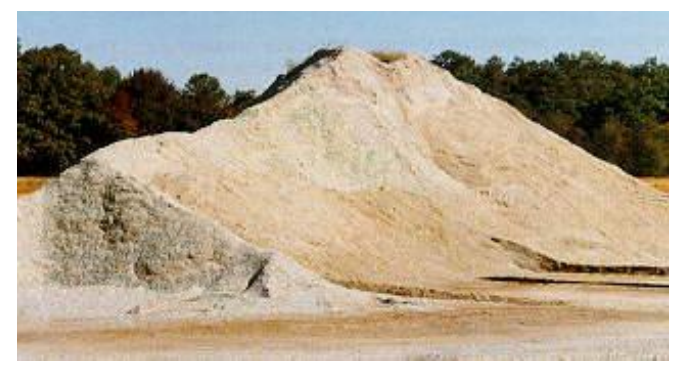

Figure (1) Pile of Cement Kiln dust located at an asphalt plant

Generally, replacing cement -partially- with supplementary cementitious waste materials (SCWM) in concrete will save energy, protect the environment, and conserve natural resources. According to Malvar et al. (2002), replacing 25\% of all cements used in concrete with SCWMs could save the U.S. economy more than $\$ 1$ billion per year. The replacement of conventional Portland cement with SCWM s have been worldwide, in particularly on how these materials impacted concrete properties. The common SCWMs studied include, but may not be limited to, fly ash, furnace slag, and silica fume. Results showed that depending on the type of raw material and percentage of replacement, concrete properties could be enhanced or negatively impacted compared with that of conventional concrete.

It's clear that construction material behavior is very dependable on the SCWM properties which are usually varied based on many factors (i.e. manufacturing process, industry raw materials properties, recycling process...etc). Therefore, it is necessary to investigate the implementation of different local SCWM on the produced green construction material properties regardless the results observed with using the same SCWM under different factors. Simply, it's very important to study various conditions of SCWM and the corresponding produced construction material having data base and an industry standards to convince the construction manufacturers to relay on these new green construction materials.

\section{2- $\quad$ Research Objectives}

A comprehensive research program is running currently to study the most efficient procedures for recycling some common local industrial wastes in production of construction materials and improving local soil (commonly found in middle delta region) compaction characteristics. Previous research works, worldwide, had proved the promising application of recycling cement kiln dust (i.e. bypass) and ceramics powder for different construction applications. However, with using the local wastes, it's essential to explore such recycling efficiency of these wastes based on their exact condition (e.g. chemical composition and their 
activity) at various storage phases. The main objectives of this research are to explore the feasibility of recycling cement kiln dust (i.e. bypass) and ceramics powder wastes in production of construction materials and improving the soil compaction. Therefore the following points are investigated:

1- The main characteristics of freshly produced cement kiln dust and ceramics powder wastes selected samples.

2- The performance of mortar samples made using the cement kiln dust and ceramics powder wastes selected samples as partial replacement of cement.

3- Based on the results of mortar mixes testing, performance of concrete samples made using the cement kiln dust or ceramics powder wastes, as partial replacement of cement, were investigated.

4- The compaction properties of weak soil modified with cement kiln dust.

Based on the results this exploratory investigation, similar application will be implemented for wider selection of these wastes at different manufacturing conditions and storage conditions as well as various storage periods. The huge results of such comprehensive study are expected to be a good source for data base for recycling cement kiln dust and ceramics powder wastes in producing green construction materials. Such data base provides reliable source, among many other sources, for establishment guide lines for using these wastes in various construction applications.

\section{3- Experimental program}

\section{Materials and testing}

1- Mortar and concrete constituents

a- Aggregate

The fine aggregate used, in this research work, was quartz sand passing from $4.75 \mathrm{~mm}$ sieve and retained on $0.15 \mathrm{~mm}$ sieve with fineness modulus of 2.52 and specific gravity of 2.5 . The coarse aggregate used was dolomite with maximum nominal size of $10 \mathrm{~mm}$ and specific gravity of 2.67. Both aggregate types were used in saturated surface dry condition and were complied with the limits of the Egyptian code of practice (ECP 203-2008, vol. 3).

b- Cementitious materials

\section{Portland cement}

CEM I 32.5 N was used and it was tested out as per the Egyptian Standard Specifications ESS 2421/2007. The used cement was complied with the limits of ESS 4756-1/2009. Potable tap water was used for concrete mixing all through the study. Chemical analysis was performed on the cement sample to determine the ratios of different cement oxides to be compared with that of the supplementary cementitious waste materials. 


\section{Cement kiln dust, hydrated lime and ceramic powder waste}

Cement kiln dust (CKD) batch, freshly produced from Tourah Portland Cement Factory, was used in this research work. Lime was also used, as it has the closer calcium oxide to cement and that expected to CKD. In addition, ceramic powder waste batch was extracted from land fill area assigned for the ceramic manufacturing wastes at one of the biggest ceramic factories in Egypt. Chemical analysis was performed on, cement, lime, cement kiln dust and ceramic powder waste samples to determine thier composition.

\section{Fly ash and Silica fume}

Silica fume (SF) and fly ash (FA) were used as pozzolanic materials for mortar and concrete samples. Silica fume (Master Life SF 100) produced by BASF Egypt and fly ash (Type F) produced by SIKA Egypt were used for mortar and concrete mixes. Table (1) shows the chemical analysis of various cementitious materials used in this research work.

Table (1) Chemical analysis of various cementitious materials

\begin{tabular}{|c|c|c|c|c|c|c|}
\hline Oxides & $\begin{array}{c}\text { CEM I } \\
\mathbf{4 2 . 5} \mathbf{~ N}\end{array}$ & Fly ash & $\begin{array}{c}\text { Silica } \\
\text { fume }\end{array}$ & $\begin{array}{c}\text { Cement } \\
\text { kiln dust }\end{array}$ & Lime & $\begin{array}{c}\text { Ceramic } \\
\text { powder waste }\end{array}$ \\
\hline $\mathbf{S i O}_{2}$ & 21.03 & 51.62 & 93.7 & 11.79 & 2.88 & 59.58 \\
\hline $\mathbf{C a O}$ & 62.98 & 3.58 & 0.82 & 33.05 & 62.58 & 0.93 \\
\hline $\mathbf{M g O}$ & 1.02 & 0.777 & .444 & 2.006 & 1.006 & 0.36 \\
\hline $\mathbf{F e}_{2} \mathbf{O}_{3}$ & 3.95 & 2.006 & 0.8 & 3.006 & 0.25 & 2.1 \\
\hline $\mathbf{A l}_{2} \mathbf{O}_{3}$ & 4.75 & 37.19 & 1.9 & 5.2 & 5.4 & 23.2 \\
\hline $\mathbf{S O}_{3}$ & 2.925 & 0.18 & 0.022 & 1.54 & 0.466 & 0.26 \\
\hline $\mathbf{N a}_{2} \mathbf{O}$ & 0.47 & 0.72 & 0.72 & 9.8 & .6 & 1.23 \\
\hline $\mathbf{K}_{2} \mathbf{O}$ & 0.17 & 0.24 & 0.2 & 1.6 & .12 & 4.26 \\
\hline $\mathbf{C L}^{-}$ & 0.031 & .008 & .015 & 11.9 & .045 & 0.07 \\
\hline $\mathbf{P}_{2} \mathbf{O}_{5}$ & 0.12 & 0.8 & .05 & .06 & .01 & 0.008 \\
\hline $\mathbf{L . O . I}$ & 1.98 & 3.3 & 1.05 & 19.8 & 26.53 & 7.49 \\
\hline Total & 99.43 & 99.62 & 99.72 & 99.81 & 99.92 & 99.49 \\
\hline
\end{tabular}

\section{2-Mortar and Concrete Mixes}

A total number of 21 mortar mixes were designed with constant cementitious/fine aggregate ratio $=1 / 3$ and constant water/binder $(\mathrm{w} / \mathrm{b})=0.5$ keeping a tight range of flow percentage of $80-110 \%$ by the help of using Sikament $163 \mathrm{M}$ plasticizer. Calcium Chloride $\left(\mathrm{Ca}^{\mathrm{Cl}} 2\right)$ and gypsum had replaced $2 \%$ of the cementitious material for some mortar mixes to control the observed mortar early stiffening delay. Table (2) shows different mortar mixes and the proportions of their cementitious material. Compressive strength of different cement mortar specimens was determined at 7,28 and 56 days based on ASTM C 109 standard as shown in figure (2). 

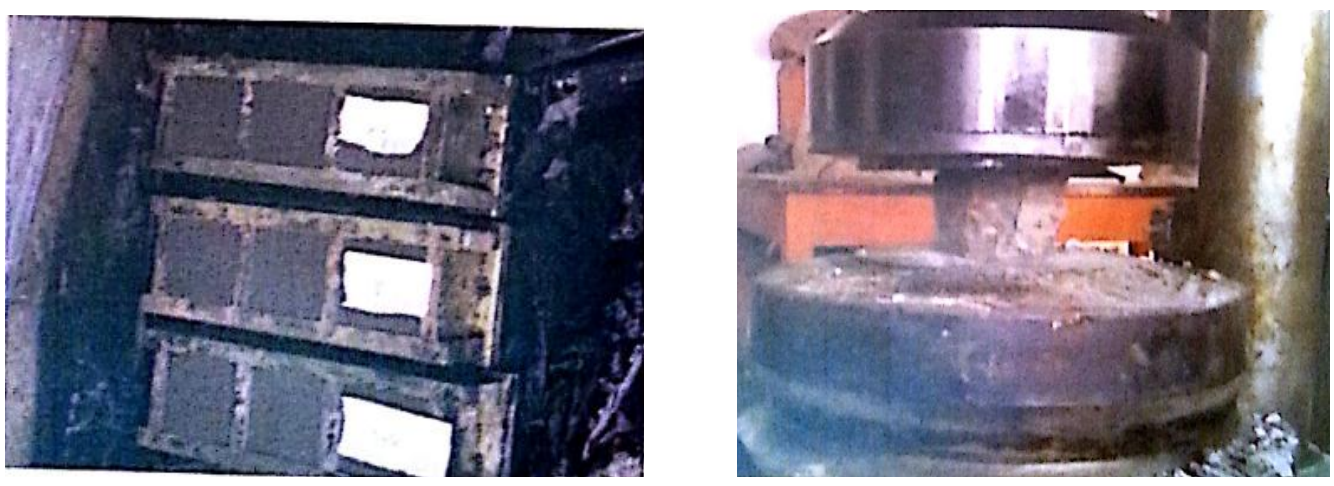

Figure (2) Preparation and testing of mortar specimens under compression according to ASTM

Table (2) Proportions (by weight) of cementitious material for different mortar mixes

\begin{tabular}{|c|c|c|c|c|c|c|c|c|c|}
\hline $\begin{array}{l}\text { Mix } \\
\text { ID }\end{array}$ & $\begin{array}{l}\text { Specimen } \\
\text { Code }\end{array}$ & $\begin{array}{c}\text { Cemen } \\
\mathbf{t} \\
\%\end{array}$ & $\begin{array}{c}\text { Fly } \\
\text { ash } \\
\%\end{array}$ & $\begin{array}{c}\text { Silica } \\
\text { fume } \\
\%\end{array}$ & $\underset{\%}{\text { Lime }}$ & $\begin{array}{c}\text { CKD } \\
\text { (Bypass } \\
\text { ) }\end{array}$ & $\begin{array}{c}\text { Ceramic } \\
\text { powder } \\
\text { waste } \\
(\mathrm{CPW})\end{array}$ & $\underset{\%}{\text { Cacl2 }}$ & $\underset{\%}{\text { Gypsum }}$ \\
\hline $\mathbf{X 1}$ & $100 \mathrm{C}$ & 100 & & & & & & & \\
\hline $\mathrm{X} 2$ & $80 \mathrm{C} / 20 \mathrm{FA}$ & 80 & 20 & & & & & & \\
\hline $\mathbf{X 3}$ & $85 \mathrm{C} / 15 \mathrm{SF}$ & 85 & & 15 & & & & & \\
\hline $\mathbf{X} 4$ & $50 \mathrm{C} / 50 \mathrm{~L}$ & 50 & & & 50 & & & & \\
\hline $\mathbf{X 5}$ & $50 \mathrm{C} / 20 \mathrm{FA} / 30 \mathrm{~L}$ & 50 & 20 & & 30 & & & & \\
\hline X6 & $50 \mathrm{C} / 20 \mathrm{FA} / 28 \mathrm{~L} / 2 \mathrm{G}$ & 50 & 20 & & 28 & & & & 2 \\
\hline $\mathbf{X 7}$ & $50 \mathrm{C} / 20 \mathrm{FA} / 28 \mathrm{~L} / 2 \mathrm{CA}$ & 50 & 20 & & 28 & & & 2 & \\
\hline $\mathbf{X 8}$ & $63 \mathrm{C} / 20 \mathrm{FA} / 15 \mathrm{~L} / 2 \mathrm{CA}$ & 63 & 20 & & 15 & & & 2 & \\
\hline X9 & $50 \mathrm{C} / 20 \mathrm{FA} / 28 \mathrm{~B} / 2 \mathrm{CA}$ & 50 & 20 & & & 28 & & 2 & \\
\hline $\mathbf{X 1 0}$ & $13 \mathrm{C} / 60 \mathrm{FA} / 25 \mathrm{~L} / 2 \mathrm{CA}$ & 13 & 60 & & 25 & & & 2 & \\
\hline $\mathbf{X 1 1}$ & $50 \mathrm{C} / 50 \mathrm{~B}$ & 50 & & & 50 & & & & \\
\hline $\mathbf{X 1 2}$ & $13 \mathrm{C} / 60 \mathrm{FA} / 25 \mathrm{~B} / 2 \mathrm{CA}$ & 13 & 60 & & & 25 & & 2 & \\
\hline $\mathbf{X 1 3}$ & $63 \mathrm{C} / 20 \mathrm{FA} / 15 \mathrm{~B} / 2 \mathrm{CA}$ & 63 & 20 & & & 15 & & 2 & \\
\hline X14 & $63 \mathrm{C} / 10 \mathrm{FA} / 25 \mathrm{~L} / 2 \mathrm{CA}$ & 63 & 10 & & 25 & & & & \\
\hline $\mathbf{X 1 5}$ & $63 \mathrm{C} / 10 \mathrm{FA} / 25 \mathrm{~B} / 2 \mathrm{CA}$ & 63 & 10 & & 25 & & & 2 & \\
\hline X16 & 80C/10FA/10L & 80 & 10 & & 10 & & & & \\
\hline $\mathbf{X 1 7}$ & 80C/10FA/10B & 80 & 10 & & & 10 & & & \\
\hline X18 & $13 \mathrm{C} / 30 \mathrm{FA} / 55 \mathrm{~L} / 2 \mathrm{CA}$ & 13 & 30 & & 55 & & & 2 & \\
\hline X19 & $13 \mathrm{C} / 30 \mathrm{FA} / 55 \mathrm{~B} / 2 \mathrm{CA}$ & 13 & 30 & & & 55 & & 2 & \\
\hline $\mathrm{X20}$ & $85 \mathrm{C} / 15 \mathrm{CP}$ & 85 & & & & & 15 & & \\
\hline X21 & $70 \mathrm{C} / 30 \mathrm{CP}$ & 70 & & & & & 30 & & \\
\hline
\end{tabular}

Based on the testing results of the mortar, 7 concrete mixes were chosen for concrete performance exploratory study. Table (3) shows different concrete mixes investigated in this research work. Water/cement ratio $=0.57$ was kept constant for all concrete specimens and a tight range of concrete slump of $60-80 \mathrm{~mm}$ by the help of using Sikament $163 \mathrm{M}$ plasticizer. The compressive strength of various concrete specimens -at 7 and 28 days- was determined based on the ECP 203-2008, vol. 3. 
Table (3) Different concrete mixes

\begin{tabular}{|c|c|c|c|c|c|c|c|c|c|c|c|}
\hline Mix & Specimen & \multicolumn{7}{|c|}{ Cementitious Material } & \multirow{2}{*}{$\begin{array}{r}\text { Fine } \\
\text { Agg. } \\
\\
\mathrm{Kg}\end{array}$} & \multirow{2}{*}{$\begin{array}{c}\text { Coarse } \\
\text { Agg. } \\
\\
\text { Kg }\end{array}$} & \multirow{2}{*}{$\begin{array}{c}\text { Admixture } \\
\mathrm{Kg}\end{array}$} \\
\hline & & $\begin{array}{c}\text { Cement } \\
\mathrm{Kg}\end{array}$ & $\begin{array}{l}\text { Fly } \\
\text { ash } \\
\mathrm{Kg}\end{array}$ & $\begin{array}{c}\text { Silic } \\
\text { a } \\
\text { fume } \\
\mathrm{Kg}\end{array}$ & $\begin{array}{c}\text { Lim } \\
\text { e } \\
\mathrm{Kg}\end{array}$ & $\begin{array}{c}\text { Bypas } \\
\mathbf{s} \\
\mathrm{Kg}\end{array}$ & $\begin{array}{l}\text { CP } \\
\mathbf{W} \\
\mathrm{Kg}\end{array}$ & $\begin{array}{l}\text { Cac } \\
\mathbf{l}_{2} \\
\mathrm{Kg}\end{array}$ & & & \\
\hline C1 & $100 \mathrm{C}$ & 300 & & & & & & & 630 & 1260 & 3.07 \\
\hline $\mathrm{C2}$ & $80 \mathrm{C} / 20 \mathrm{FA}$ & 240 & 60 & & & & & & 630 & 1260 & \\
\hline $\mathbf{C 3}$ & $85 \mathrm{C} / 15 \mathrm{SF}$ & 255 & & 45 & & & & & 630 & 1260 & 5.75 \\
\hline C4 & $\begin{array}{c}50 \mathrm{C} / 20 \mathrm{FA} / 2 \\
8 \mathrm{~L} / 2 \mathrm{CA}\end{array}$ & 150 & 60 & & 84 & & & 6 & 630 & 1260 & \\
\hline C5 & $\begin{array}{c}50 \mathrm{C} / 20 \mathrm{FA} / 2 \\
8 \mathrm{~B} / 2 \mathrm{CA}\end{array}$ & 150 & 60 & & & 84 & & 6 & 630 & 1260 & \\
\hline C6 & $\begin{array}{c}63 \mathrm{C} / 10 \mathrm{FA} / 2 \\
5 \mathrm{~B} / 2 \mathrm{CA}\end{array}$ & 189 & 30 & & & 75 & & 6 & 630 & 1260 & \\
\hline C7 & $85 \mathrm{C} / 15 \mathrm{CP}$ & 255 & & & & & 45 & & 630 & 1260 & 6.9 \\
\hline
\end{tabular}

\section{Soil}

Based on the AASHTO notation for classification, A-7-6 class soil was selected to be modified by Cement kiln dust (CKD). Table (4) shows the description of different soil specimens. For these soil samples, PH value and Atterberg limits as well as compaction performance were determined. Compaction performance testing included the determination of the following properties for each soil specimen:

1- Optimum Moisture Content (OMC)

2- Maximum Dry Density (MDD)

3- Stress- penetration performance and California Bearing Ratio (CBR).
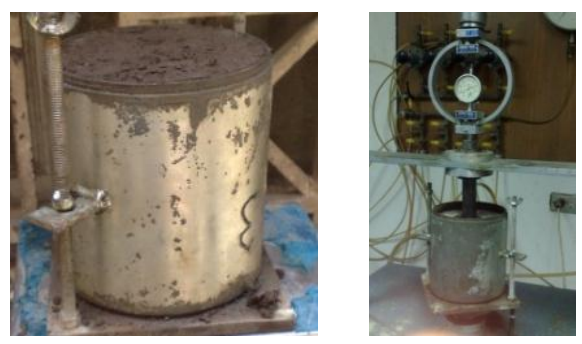

Figure (3) Soil specimen preparation and testing. 
Table (4) Description of soil samples

\begin{tabular}{|c|c|}
\hline $\begin{array}{c}\text { Soil } \\
\text { Specimen ID }\end{array}$ & Description \\
\hline Soil- Cont & A-7-6 soil class according to AASHTO \\
\hline $\begin{array}{c}\text { Soil }-3 \% \\
\text { CKD }\end{array}$ & Soil $+3 \%$ Cement kiln dust (CKD) \\
\hline $\begin{array}{c}\text { Soil }-6 \% \\
\text { CKD }\end{array}$ & Soil $+6 \%$ Cement kiln dust (CKD) \\
\hline $\begin{array}{c}\text { Soil }-9 \% \\
\text { CKD }\end{array}$ & Soil $+9 \%$ Cement kiln dust (CKD) \\
\hline
\end{tabular}

\section{4- $\quad$ Results and discussions}

\section{1-Mortar specimens}

Table (5) shows the compressive strength of different mortar specimens at various ages. Figure (4) shows a comparison between the compressive strength at different ages for all mortar specimens.

Table (5) Compressive strength of different mortar specimens at various ages

\begin{tabular}{|c|c|c|c|c|}
\hline \multirow[t]{2}{*}{ Mix ID } & \multirow{2}{*}{$\begin{array}{l}\text { Specimen } \\
\text { code }\end{array}$} & \multicolumn{3}{|c|}{ Average Compressive Strength } \\
\hline & & $\begin{array}{c}\text { (7 days) } \\
\mathrm{MPa}\end{array}$ & $\begin{array}{c}\text { (28 days) } \\
\mathrm{MPa}\end{array}$ & $\begin{array}{c}\text { (56 days) } \\
\mathrm{MPa}\end{array}$ \\
\hline X1 & $100 \mathrm{C}$ & 14.6 & 18.1 & 18.9 \\
\hline $\mathbf{X} 2$ & $80 \mathrm{C} / 20 \mathrm{FA}$ & 8.69 & 13.33 & 16.22 \\
\hline $\mathbf{X 3}$ & $85 \mathrm{C} / 15 \mathrm{SF}$ & 8.93 & 12.9 & 19.3 \\
\hline $\mathbf{X 4}$ & $50 \mathrm{C} / 50 \mathrm{~L}$ & 4.85 & 6.23 & 7.44 \\
\hline $\mathbf{X 5}$ & 50C/20FA/30L & 5.66 & 8.3 & 10.55 \\
\hline X6 & $50 \mathrm{C} / 20 \mathrm{FA} / 28 \mathrm{~L} / 2 \mathrm{G}$ & 6.03 & 9.1 & 11.5 \\
\hline $\mathbf{X 7}$ & $50 \mathrm{C} / 20 \mathrm{FA} / 28 \mathrm{~L} / 2 \mathrm{CA}$ & 4.8 & 9.01 & 12.43 \\
\hline $\mathbf{X 8}$ & $63 \mathrm{C} / 20 \mathrm{FA} / 15 \mathrm{~L} / 2 \mathrm{CA}$ & 8.32 & 12.25 & 13.27 \\
\hline X9 & $50 \mathrm{C} / 20 \mathrm{FA} / 28 \mathrm{~B} / 2 \mathrm{CA}$ & 5.75 & 11.45 & 13.82 \\
\hline $\mathbf{X 1 0}$ & 13C/60FA/25L/2CA & 0.34 & 2.36 & 4.6 \\
\hline $\mathbf{X 1 1}$ & $50 \mathrm{C} / 50 \mathrm{~B}$ & 7.41 & 8.74 & 9.77 \\
\hline $\mathbf{X 1 2}$ & $13 \mathrm{C} / 60 \mathrm{FA} / 25 \mathrm{~B} / 2 \mathrm{CA}$ & 2.1 & 4.87 & 7 \\
\hline $\mathbf{X 1 3}$ & $63 \mathrm{C} / 20 \mathrm{FA} / 15 \mathrm{~B} / 2 \mathrm{CA}$ & 11.39 & 14.24 & 17.3 \\
\hline X14 & $63 \mathrm{C} / 10 \mathrm{FA} / 25 \mathrm{~L} / 2 \mathrm{CA}$ & 7.28 & 9.33 & 10.14 \\
\hline $\mathbf{X 1 5}$ & $63 \mathrm{C} / 10 \mathrm{FA} / 25 \mathrm{~B} / 2 \mathrm{CA}$ & 9.88 & 12.8 & 15.6 \\
\hline $\mathbf{X 1 6}$ & $80 \mathrm{C} / 10 \mathrm{FA} / 10 \mathrm{~L}$ & 12.45 & 14.53 & 17 \\
\hline $\mathbf{X 1 7}$ & 80C/10FA/10B & 12.40 & 14.9 & 17.5 \\
\hline $\mathbf{X 1 8}$ & $13 \mathrm{C} / 30 \mathrm{FA} / 55 \mathrm{~L} / 2 \mathrm{CA}$ & 0.55 & 1.6 & 3.33 \\
\hline $\mathbf{X 1 9}$ & $13 \mathrm{C} / 30 \mathrm{FA} / 55 \mathrm{~B} / 2 \mathrm{CA}$ & 1.55 & 3.79 & 5.4 \\
\hline $\mathbf{X} 20$ & $85 \mathrm{C} / 15 \mathrm{CP}$ & 9.4 & 13.5 & 16.6 \\
\hline $\mathbf{X} 21$ & $70 \mathrm{C} / 30 \mathrm{CP}$ & 7.3 & 10.1 & 12.3 \\
\hline
\end{tabular}




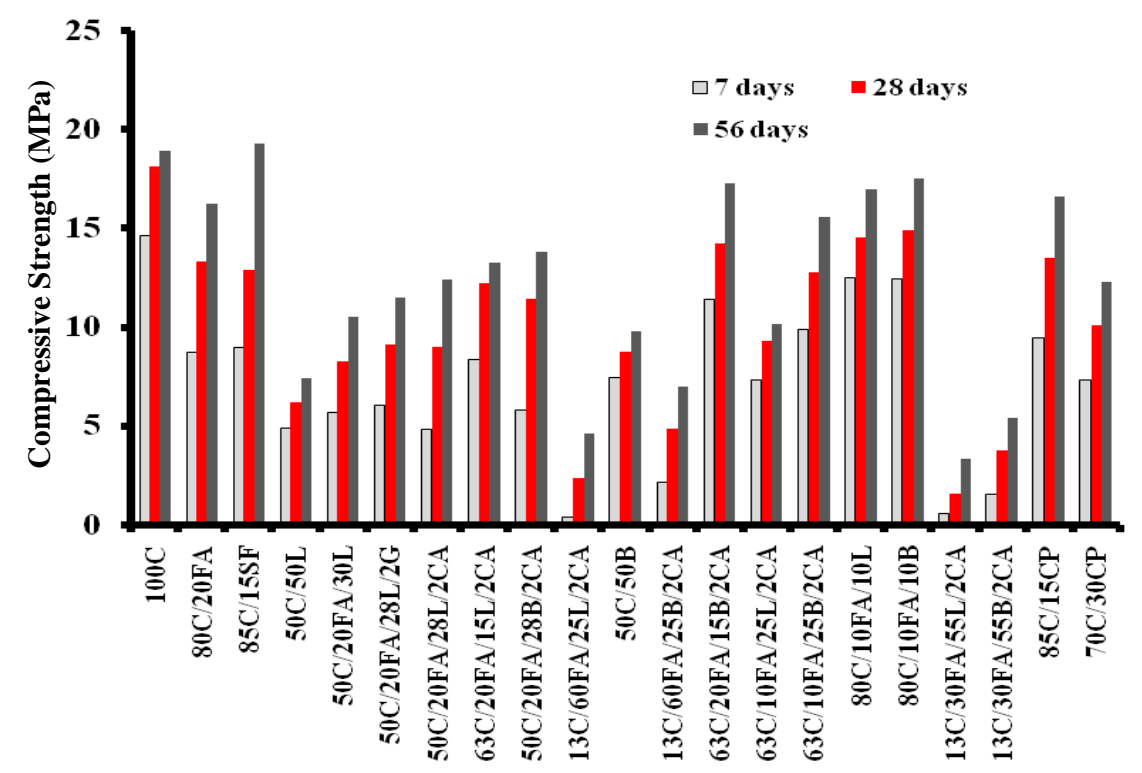

Figure (4) Comparison between the compressive strength at different ages for all mortar

\section{Different mortar specimens}

Figures (5) through (7) show the compressive strength progress for some selective mortar specimens. Figure (5) shows the strength progress for mortar specimens had maximum and minimum strength compared to the pure cement specimen and cement specimens blended with fly ash and with silica fume. Figure (6) and Figure (7) show the strength progress of mortar specimens blended with CKD and ceramic powder waste respectively and compared with pure cement.

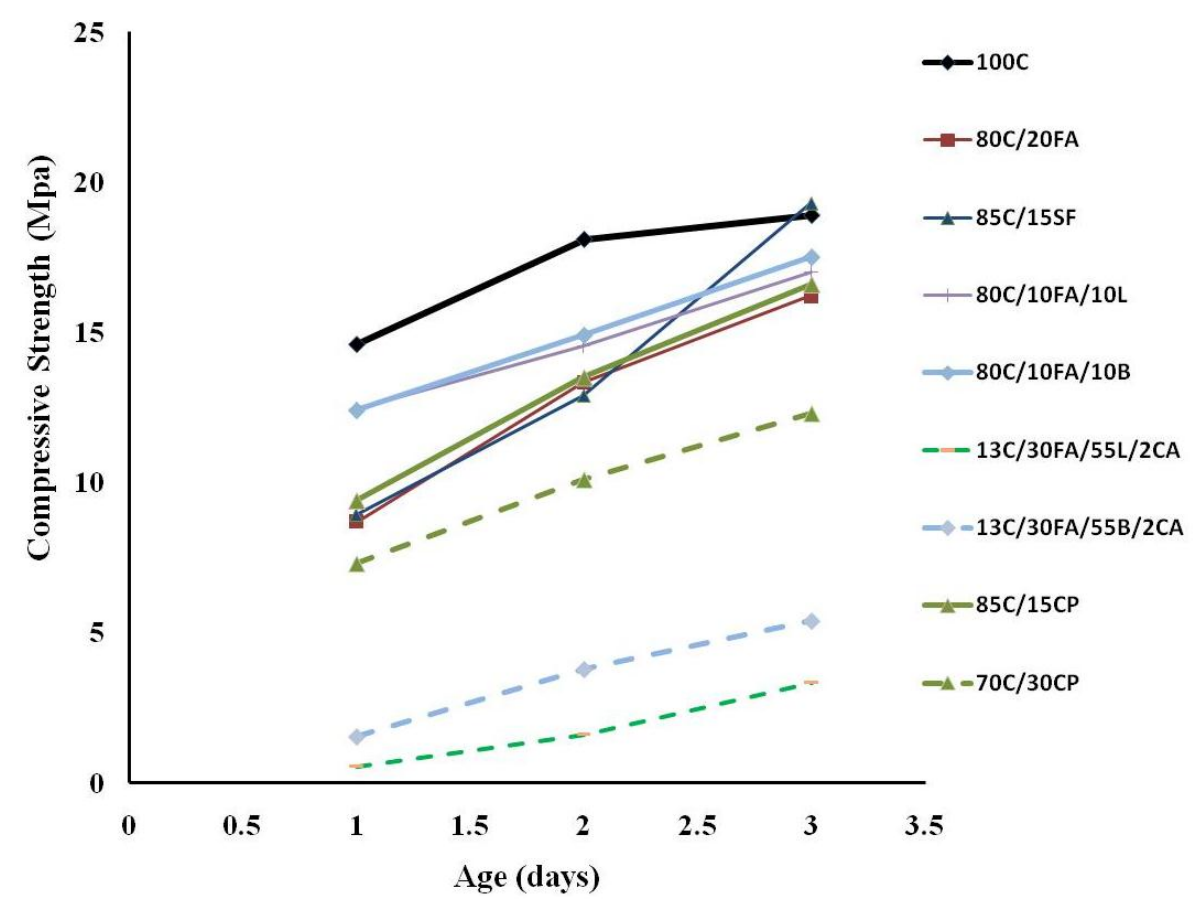

Figure (5) Compressive strength progress of mortar specimens had maximum and minimum compared to pure cement and cement blended with fly ash and with silica fume. 


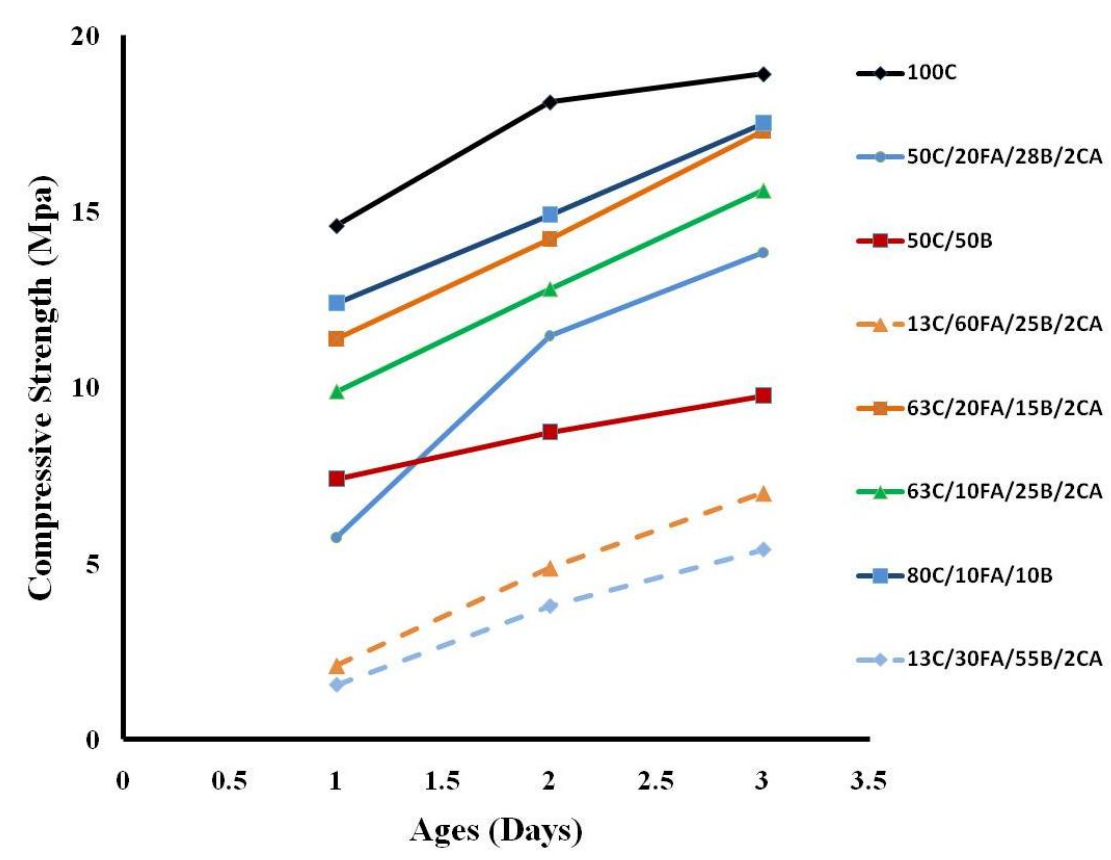

Figure (6) Compressive strength progress of mortar specimens blended

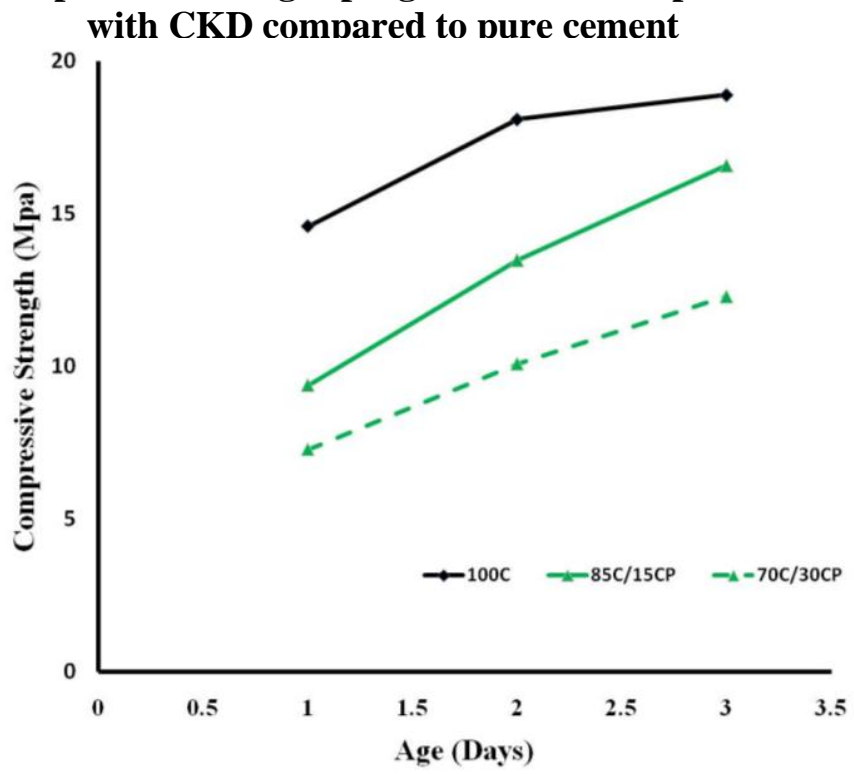

Figure (7) Compressive strength progress of mortar specimens blended with ceramic powder waste compared to pure cement

Referring to the compressive strength progress of different tested mortar specimens, the following points can be extracted:

1- Blending lime or freshly produced cement kiln dust with pozzolanic materials (fly ash or silica fume) to replace cement partially didn't increase the mortar compressive strength. However, adding replacing $20 \%$ of cement with equal parts of fly ash and CKD reached $93 \%$ of compressive strength for the mortar mix made with pure cement at 56 days.

2- Specimens made of the freshly produced CKD had provided higher compressive strength and strength progress than specimens made of lime having the same cement 
replacement ratio. This is due to the lower loss of ignition ratio of the selected CKD compared to the used lime. On the other hand, high chloride content of CKD compared to lime can be another reason for its better strength performance.

3- Replacing $15 \%$ of cement with ceramic provided better strength and strength progress than $30 \%$ replacement even though it didn't reached more than $88 \%$ of the strength compared to the full cement specimen. However, replacing $15 \%$ of cement with ceramic powder wastes provided slightly higher strength than replacing $20 \%$ of cement with fly ash which may be to the slightly higher Silica or due to the difference in the cement replacement (5\% difference). The pozzolanic performance of the selected ceramic powder wastes compared to fly ash need to be verified with further deep study.

\section{2-Concrete specimens}

Table (6) and Figure (8) show the compressive strength of different concrete specimens at various ages. Concrete specimens performance verified most some of the points observed with replacing cement with CKD or ceramic powder waste.

Table (6) Compressive strength of different concrete specimens at various ages

\begin{tabular}{|c|c|c|c|c|}
\hline \multirow[t]{2}{*}{ Mix ID } & \multirow{2}{*}{$\begin{array}{l}\text { Specimen } \\
\text { Code }\end{array}$} & \multicolumn{3}{|c|}{ Average Compressive Strength } \\
\hline & & $\begin{array}{c}\text { (7 days) } \\
\mathrm{MPa}\end{array}$ & $\begin{array}{c}\text { (28 days) } \\
\mathrm{MPa}\end{array}$ & $\begin{array}{c}\text { (56 days) } \\
\mathrm{MPa}\end{array}$ \\
\hline C1 & $100 \mathrm{C}$ & 21.7 & 25.4 & 26.5 \\
\hline $\mathbf{C 2}$ & $80 \mathrm{C} / 20 \mathrm{FA}$ & 18.9 & 22.6 & 24.8 \\
\hline C3 & $85 \mathrm{C} / 15 \mathrm{SF}$ & 21.0 & 24.8 & 27.5 \\
\hline $\mathbf{C 4}$ & $50 \mathrm{C} / 20 \mathrm{FA} / 28 \mathrm{~L} / 2 \mathrm{CA}$ & 4.5 & 5.7 & 8.44 \\
\hline C5 & $50 \mathrm{C} / 20 \mathrm{FA} / 28 \mathrm{~B} / 2 \mathrm{CA}$ & 6.7 & 8.2 & 10.55 \\
\hline C6 & $63 \mathrm{C} / 10 \mathrm{FA} / 25 \mathrm{~B} / 2 \mathrm{CA}$ & 9.1 & 13.4 & 17.9 \\
\hline C7 & $85 \mathrm{C} / 15 \mathrm{CP}$ & 15.8 & 19.7 & 23.4 \\
\hline
\end{tabular}

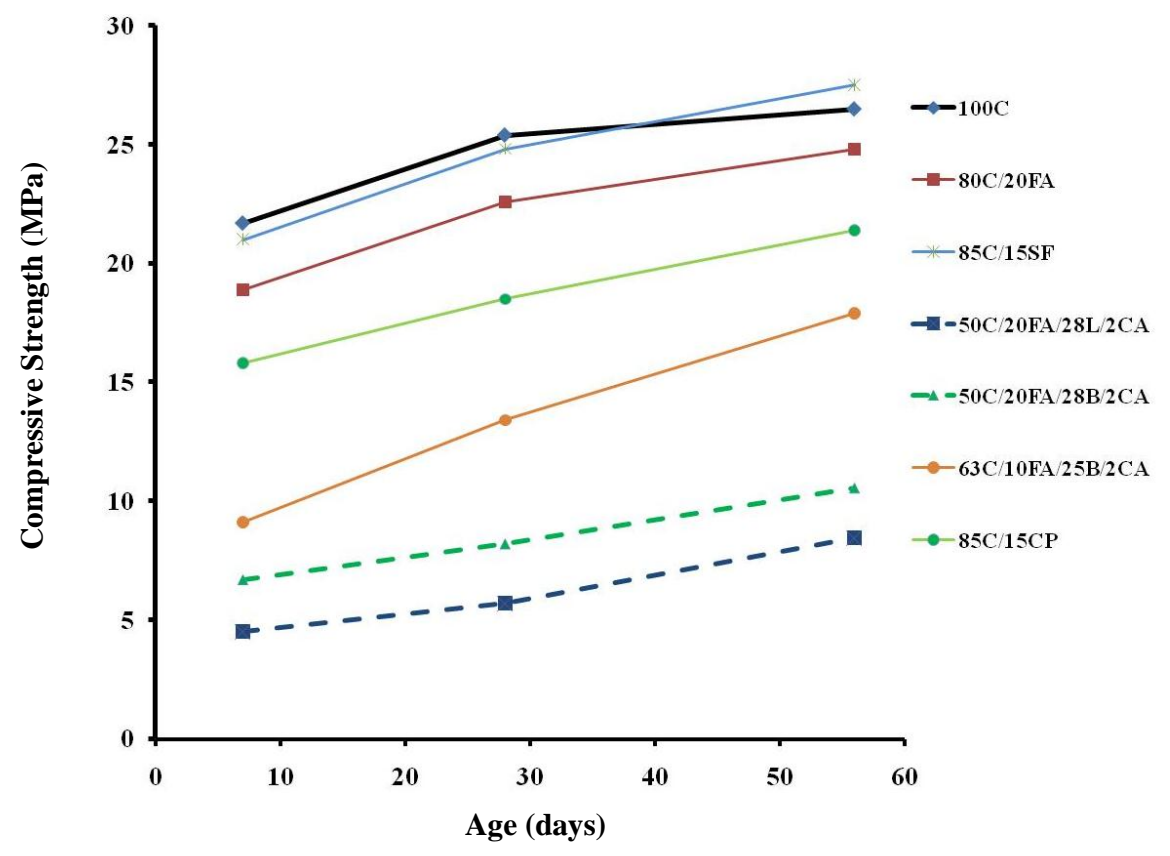

Figure (8) Compressive strength ${ }_{3}$ progress of all concrete specimens 


\section{3-Soil specimens}

Table (7) and figures (9) and (10) show the characteristics of soil specimens. Referring to the soil measured characteristics, the following points can be extracted:

1- Increasing the added CKD ratio, increased the tested soil PH value (as highly alkaline material) and the soil optimum moisture content as well as decreased its maximum dry density. However, the soil plasticity index had changed depending on the added CDK ratio.

2- Significant enhancement recorded in the soil stiffness by add CDK to soil sample as shown in stress-penetration curves for different modified soil samples, see Figure (10). Generally, CBR value of the soil had reached $340 \%$ of the original value of the tested soil by adding $9 \%$ of CKD.

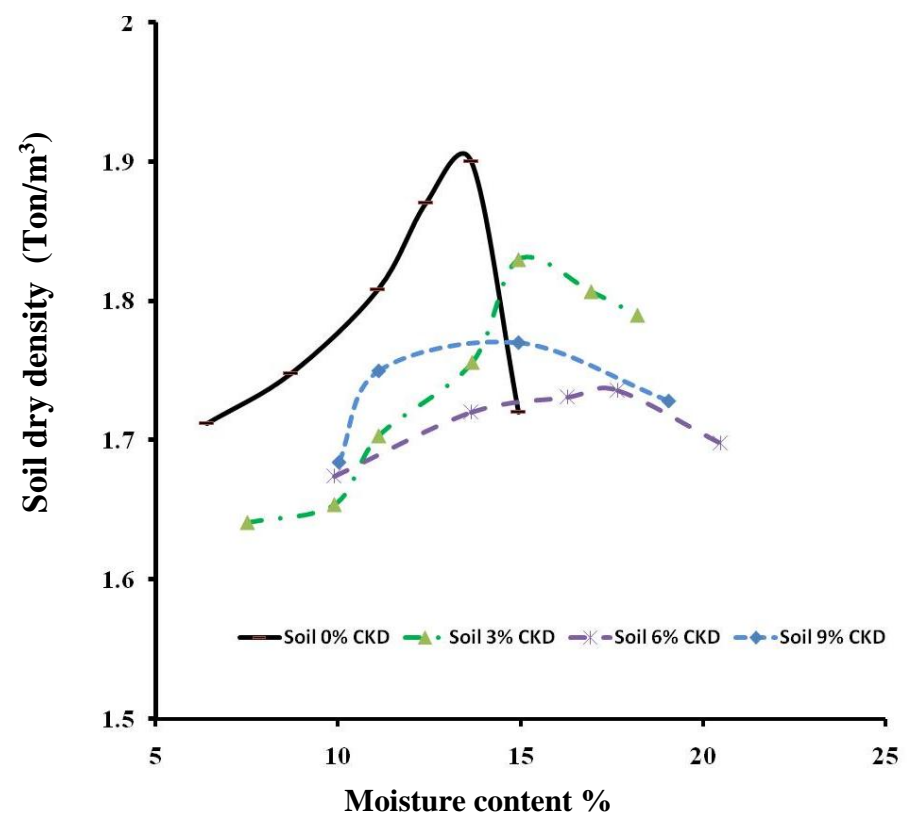

Figure (9) Dry density vs moisture content for all soil specimens

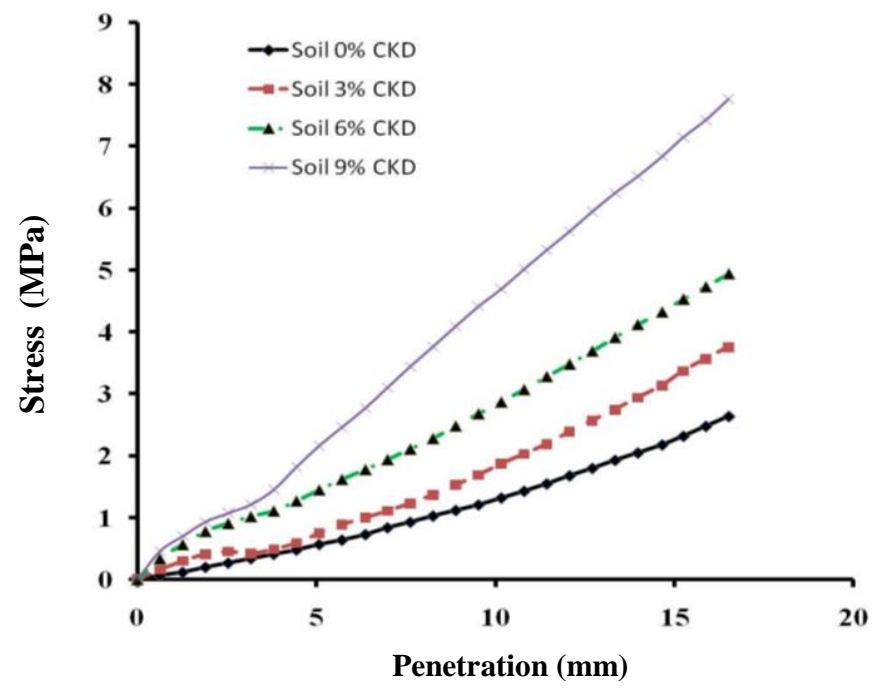

Figure (10) Stress penetration curves for all soil specimens 
TABLE (7) The main characteristics for different soil specimens

\begin{tabular}{|c|c|c|c|c|c|c|c|}
\hline $\begin{array}{c}\text { Soil } \\
\text { Specimen ID }\end{array}$ & PH & $\begin{array}{c}\text { Liquid } \\
\text { Limit } \\
\mathbf{\%}\end{array}$ & $\begin{array}{c}\text { Plastic } \\
\text { Limit } \\
\mathbf{\%}\end{array}$ & $\begin{array}{c}\text { Plasticity } \\
\text { Index } \\
\mathbf{\%}\end{array}$ & $\begin{array}{c}\text { Max } \\
\mathbf{d r y} \\
\mathbf{d e n s i t y} \\
\mathbf{( t / \mathbf { m } ^ { 3 } )}\end{array}$ & $\begin{array}{c}\text { Optimu } \\
\mathbf{m} \\
\text { moisture } \\
\mathbf{c o n t e n t} \\
\mathbf{\%}\end{array}$ & $\begin{array}{c}\text { CBR } \\
\text { Value } \\
\mathbf{\%}\end{array}$ \\
\hline Soil- Cont & 9.3 & 49.9 & 29.5 & 20.4 & 1.9 & 13.65 & 7.3 \\
\hline Soil - 3\% CKD & 10.9 & 65.2 & 37.6 & 27.6 & 1.83 & 15.04 & 10.77 \\
\hline Soil - 6\% CKD & 11 & 60.7 & 40.7 & 19.7 & 1.74 & 16.8 & 14.08 \\
\hline Soil - 9\% CKD & 11.1 & 56.3 & 38.9 & 17.4 & 1.77 & 14.98 & 24.9 \\
\hline
\end{tabular}

\section{5- Conclusions}

Based on test results, the following conclusions are drawn:

1. Based on the selected conditions of the cement bypass and ceramic powder, no significant enhancement was recorded in the compressive strength of the mortar and concrete mixes had various ratios of CKD cement replacement. However, the compressive strength of some of the tested mixes provided promising values for production of green plain concrete (i.e. not suitable for reinforced concrete for its high chloride content), mortar and bricks. In addition, providing an added value for this environment harmful wastes will encourages cement manufacturers to recycle CKD in many construction fields.

2. Adding CKD bypass to the weak selected soil increased the soil stiffness significantly and enhanced soil California Bearing Ratio (CBR) value reached 340\%. Such application needs further assessment to have a data base for various soil types in Egypt and the appropriate CKD mixing ratio to provide low capacity roads widely for rural and desert areas using such green stabilized soil.

3. The chemical analysis of the selected ceramic powder waste and its performance which compete with fly ash, highlights the importance of such waste for further study as proposed sustainable source of pozzolanic material.

\section{6- $\quad$ Further Study}

Comprehensive study needs to be performed to investigate, seriously, how to provide practical opportunity to recycle many industrial wastes (e.g. CKD and ceramic powder waste) in construction applications materials. Such effort will provide an economic added value for these wastes which will cover the existing gap between providing promising research lab results for recycling residues and applying it in the main sources of the residues accordingly assure sustainable recycling process of such residues. Currently more than research program are running in the Material Testing Laboratory- Faculty of Engineering - Tanta University to investigate the opportunities for recycling wide range of industrial wastes commonly found in Egypt and specially at delta region. 


\section{7- REFERENCES}

Aïtcin P.C. , (2008), Binders for durable and sustainable concrete, Taylor and Francis, London, $500 \mathrm{p}$.

Barger, Gregory S.; Lukkarila, Mark R.; Martin, David L.; Lane, Steven B.; Hansen, Eric R.; Ross, Matt W.; and Thompson, Jimmie L. (1997). "Evaluation of a Blended Cement and a Mineral Admixture Containing Calcined Clay Natural Pozzolan for HighPerformance Concrete, " Proceedings of the Sixth International Purdue Conference on Concrete Pavement Design and Materials for High Performance, Purdue University, West Lafayette, Indiana, 1997, 21 pages.

Collins R.J. and S.K. Ciesielski. Recycling and Use of Waste Materials and Byproducts in Highway Construction, Volumes 1 \& 2, 1993.

Ghorab H.Y. , A. Anter and H. El. Miniawy, Building with Local Materials: Stabilized Soil and Industrial Wastes., Material and Manufacturing Processes, 22:157-12-2007.

Malvar, L. J.; Cline, G. D.; Burke, D. F.; Rollin gs, R.; Sherman, T. W.; and Greene, J., 2002, "Alkali Silica Reaction Mitig ation: State-of-the-Art and Recommendations," ACI Materials Journal, V. 99, No. 5, Sept.-Oct., pp. 480-489.

Robin L. Schroeder The Use of Recycled Materials in Highway Construction, Public Roads, Autumn1994, Vol. 58 - No. 2.

Tara Sen and Umesh Mishra, of Industrial Waste Products in Village Road Construction, International Journal of Environmental Science and Development, Vol. 1, No. 2, June 2010, ISSN:2010-0264 Usage.

Wayne S. Adaska and Donald H. Taubert, BENEFICIAL USES OF CEMENT KILN DUST By the Cement Industry Technical Conf., Miami, FL, May 19-22, 2008 : IEEEIAS Cement I ndustry Committee, Presented at 2008 IEEE/PCA 50.

Zimbili O., W. Salim, M. Ndambuki, Review on the Usage of Ceramic Wastes in Concrete Production World Academy of Science, Engineering and Technology, International Journal of Civil, Structural, Construction and Architectural Engineering Vol:8, No:1, 2014. 